\title{
Kindergarten Pupils' Birth Order and Domains of Early Childhood Development
}

\author{
Rene G. Nanit \\ Tarlac Agricultural University Camiling, Tarlac, Philippines. \\ Email:nanit_rene@hotmail.comTel:+639486262567
}

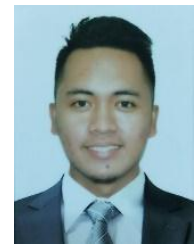

\begin{abstract}
This study aimed to find significant relationship of kindergarten pupils' birth order and achievement in domains of early childhood development (e.g., gross and fine motors, self-help, receptive and expressive languages, cognitive, and socio-emotional) using descriptivecorrelational design. A total population of 360 was reduced to 189 using Slovin's formula; respondents were chosen through random sampling. Results show that most of the kindergarten pupils are last-born children. Pupils' achievement in fine motor, receptive language, and cognitive domains was average while slightly delayed in gross motor, self-help, expressive language, and socio-emotional domains. Statistically, gross motor and expressive language domains have a significant relationship with birth order. In the gross motor, only middle born children have developed averagely; others were slightly delayed. In expressive language, only-child kindergarten pupils perform better than the other birth order. With this, teachers should consider birth order in providing learning opportunities to develop gross motor and expressive language.
\end{abstract}

Keywords: Kindergarten, Birth order, Achievement, Fine motor skills, Gross motor skills, Self-help skills, Receptive language skills, Expressive language skills, Cognitive skills, Socio-emotional skills.

JEL Classification: I29.

Citation | Rene G. Nanit (2020). Kindergarten Pupils' Birth Order and Domains of Early Childhood Development. Asian Journal of Social Sciences and Management Studies, 7(2): 143-151. Social Scienct

Received: 19 March 2020

Revised: 24 April 2020

Accepted: 26 May 2020

Published: 4 June 2020

Licensed: This work is licensed under a Creative Commons

Attribution 3.0 License (cc) E E

Publisher: Asian Online Journal Publishing Group
Funding: This paper was funded by my institution, the Tarlac Agricultural University.

Competing Interests: The author declares that there are no conflicts of interests regarding the publication of this paper.

Transparency: The author confirms that the manuscript is an honest, accurate, and transparent account of the study was reported; that no vital features of the study have been omitted; and that any discrepancies from the study as planned have been explained.

Ethical: This study follows all ethical practices during writing.

\section{Contents}

1. Introduction 


\section{Contribution of this paper to the literature}

This study has provided empirical pieces of evidence on the achievement of kindergarten pupils in domains of early childhood development and its relationship to birth order. The study revealed a significant correlation between birth order and gross motor and expressive language domains.

\section{Introduction}

People are intrigued by the empirical eff ects of birth order on human capital growth, which has revitalized interests among researchers and academicians that are evident in several past and recent years.

Hotz and Pantano (2015) claimed that the first-borns are responsible, high achievers, and perfectionists, whereas last born and only child are mostly spoiled kids. ${ }^{1}$

The studies above are in contrast with the study of Dailey (2012) about Birth Order and Its Effect on Motivation and Academic Achievement, which revealed that birth order effects on academic achievement are so small that many more participants would be needed to find a significant impact on this study. ${ }^{2}$ Also, results indicated in the research of $\mathrm{Ha}$ and Tam (2011) that the participants of different birth positions have no significant differences in terms of academic performance and personality. ${ }^{3}$

Although some of the researchers have shown that first-born children are better at a lot of things than their younger siblings and some researchers indicated no significant differences in their academic performance, the subjects of the studies presented were teenagers and adults. That is why the researcher, being an educator in the field of early childhood education, interestingly wanted to know aside from the fact that every individual is different from another if the birth order of a child affects his/her achievement in domains of early childhood education.

Early Childhood years are a crucial stage in every learner's life. The National Association for the Education of Young Children (NAEYC) considers the teacher's role and in supporting children's development as one of their top fundamental principles. Children must function in all the developmental domains (i.e., physical, social, emotional, and cognitive) if they are to adapt to school and societal norms successfully. These domains are empirically related and inextricably intertwined in early childhood. Kindergarten is a critical year where the experiences of children nurture positive approaches to learning, which prepare the learner for the more rigorous academic expectations in the elementary grades (Copple, 2009). ${ }^{4}$

The Department of Education of the Republic of the Philippines believes that the kindergarten stage is a transition between informal literacy and formal literacy (Grade 1-12). The aforementioned is the period of highest growth and development, when the brain develops rapidly, almost at its fullest. This stage establishes a period of walking, talking, self- esteem, moral foundations, and the world's concept. At this stage, teachers should immerse children with games, plays, and activities to naturally acquire the skills/competencies for holistic development as emergent literates and be ready for formal school.

Republic Act 10157 also known as Kindergarten Education Act (Philippines, 2012) supports NAEYC's mission to nurture positive approaches to learning and prepare children to naturally acquire the skills and competencies appropriate for their holistic development. Therefore, teachers should guide the kindergarten learners using a developmentally appropriate, engaging, and creative curriculum. Thus, finding the significant relationship of kindergarten pupils' birth order and achievement in domains of early childhood development would be of great help to kindergarten teachers, practitioners and parents to successfully and efficiently undertake their roles in attaining holistic development of children. ${ }^{5}$

\section{Purpose of the Research}

This study aimed to determine the relationship of kindergarten pupils' birth order, and achievement in domains of early childhood development at Santa Ignacia North District, Tarlac, Philippines enrolled during the school year 2015-2016. Specifically, it aimed to answer the following questions:

1. How may kindergarten pupils be described in terms of their:birth order; and achievement in domains of early childhood development?

2. How does kindergarten pupils' birth order relate to their achievement in domains of early childhood development?

3. What are the implications of the study on preschool education?

\section{Methodology}

\subsection{Research Design}

The study used descriptive-correlational design to determine if there is a significant relationship between kindergarten pupils' birth order and their achievement in domains of early childhood development.

Descriptive research studies variables as they exist in their setting. There is no manipulation of experimental variables, and the main concern is to describe the status, profile, incidences or occurrences of the variables (Sicat, 2009). ${ }^{6}$ With this, the study looked for the learners' birth order and achievement in domains of early childhood development. Thus, this design is appropriate for the study. On the other hand, correctional research explores the relationship between or among variables. It studies variables without any attempt to control or manipulate them. The study aimed to find if there was a significant relationship between kindergarten pupils' birth order and their achievement in domains of early childhood development. Thus, this design is also appropriate.

\footnotetext{
${ }^{1}$ From Hotz and Pantano (2015)

${ }^{2}$ From Dailey (2012).

${ }^{3}$ From Ha and Tam (2011).

${ }^{4}$ From Copple (2009).

${ }^{5}$ From Philippines (2012).

${ }^{6}$ From Sicat (2009).
} 


\subsection{Respondents of the Study and Sampling Procedure}

The population of 360 pupils of Santa Ignacia North District during the school year 2015 - 2016 was reduced to a sample size of 189 kindergarten pupils, as computed using Slovin's formula at 0.05 degree of error. The respondents of the study were the eight (8) teachers of the 189 kindergarten pupils. The researcher used random sampling in identifying the individual kindergarten pupils in the study. Teachers gave the list of kindergarten pupils to the researcher, where he randomly selected the samples.

\subsection{Data Gathering Instrument}

The data on achievement in domains of early childhood development of the kindergarten pupils were elicited through the results of 2 nd assessment period of the Early Childhood Development Checklist, the instrument used by kindergarten teachers in the public schools. Since this instrument is standardized, no validation and reliability test is needed.

The checklist is administered in a setting familiar to the respondents. The examiner (teacher) employed various and appropriate methods to determine if the child exhibited specified behavior. These included observation, direct elicitation of the behavior from the child, and an interview of the parents(s) or caregiver(s). Each form of the ECD Checklist did not take more than 45 minutes to administer. The checklist could be administered to the child thrice within a year.

The checklist was divided into seven domains: Gross Motor, Fine motor, Self-Help, Receptive Language, Expressive Language, Cognitive, and Social-Emotional. In each domain, accomplished indicators will be counted and serve as the raw scores. After deriving the raw scores for each domain, the raw score was converted into the scaled score appropriate to the child's age using the Scaled Score Conversation Table. The computed scaled scores were interpreted. If the scaled score is 1-3, it was understood as Suggest Significant Delay in Development, which means that very few among the skills/activities prescribed in each domain in the checklist were accomplished by the child; this further means that the child was frail in the domain being assessed. If the scaled score is 4-6, it was interpreted as Suggest Significant Slight Delay in Development, which means that few among the skills/activities prescribed in each domain in the checklist were accomplished by the child; this further means that the child is weak in the domain being assessed. If the scaled score is 7-13, it was interpreted as Average Development which means that the child accomplished the average number of skills/activities prescribed in each domain in the checklist. Moreover, if the scaled score is 14-16, it was interpreted as Suggest Slightly Advanced Development which means that majority among the skills/activities prescribed in each domain in the checklist were accomplished by the child; this further means that the child is healthy in the domain being assessed. Lastly, if the scaled score is 17-19, it was interpreted as Suggest Highly Advanced Development which means that most or all of the skills/activities prescribed in each domain in the checklist were accomplished by the child; this further means that the child is robust in the field being assessed.

\subsection{Data Gathering Procedure}

In terms of the data collection, the researcher first asked permission from the division superintendent of Tarlac Province then from the district supervisor of Santa Ignacia North District, Santa Ignacia, Tarlac, and the respective principals before gathering data. When the permission was approved, the researcher went to the individual kindergarten teachers to collect data. The parent's consent was sought before the collection. Achievement of the pupils in domains of early childhood development was elicited through the result of the 2 nd assessment period of the Early Childhood Development Checklist. Observations were also conducted for more substantial information. Data gathered were analyzed and interpreted after subjecting them to statistical treatments.

\subsection{Data Analysis}

The study used simple frequency counts and percentages. The Chi-square test was used in identifying the correlation of the birth order and domains of early childhood development kindergarten pupils. Tables and figures were utilized to give the reader a comprehensive picture of the gathered data and information.

In identifying the correlation of the birth order with the kindergarten pupils' achievement in domains of early childhood development, the Chi-square test was used.

\section{Results and Discussions}

This section presents the analyses and interpretation of the data gathered from the kindergarten pupils. It also discusses the findings concerning the problems raised in the study. The data were subjected to statistical treatment through weighted means and chi-square for objective interpretation. These were presented into table forms followed by their textual interpretations.

\subsection{Birth Order}

Birth order refers to the chronological order of sibling births in a family. The birth order of the kindergarten pupils in the district was collected. Data shows that 74 out of 189 or the majority of the pupils were last-borns, followed by first-born children, and then the only child pupils. Only a few were middle-born children.

\subsection{Achievement of Kindergarten Pupils in Domains of Early Childhood Development}

The achievement of the kindergarten pupils was described in terms of their performance in the seven domains - gross motor, fine motor, self-help, receptive and expressive, cognitive, and socio-emotional. The performances were assessed through the Early Childhood Development Checklist, an instrument used by kindergarten teachers in public schools. The tool is being administered at three assessment periods within a year to measure the pupil's development. The data presented below is the result of their second assessment period. 


\subsection{Gross Motor Domain}

Gross Motor skill is the ability to control and coordinate body movements involving large muscle groups such as crawling, walking, running, skipping, jumping, and climbing. Grissmer, Grimm, Aiyer, Murrah, and Steele (2010) claimed that some of the same neural infrastructures in the brain that directs the learning process during motor development are also involved in the direction of learning in cognitive development. Hence, analyzing the motor development of young children is essential. 7

Table-1. Achievement of the kindergarten pupils in gross motor domain of early childhood development.

\begin{tabular}{|c|c|c|c|c|c|c|c|c|c|c|}
\hline \multirow[t]{2}{*}{$\begin{array}{l}\text { Birth } \\
\text { Order }\end{array}$} & \multicolumn{2}{|c|}{$\begin{array}{c}\text { Suggest } \\
\text { Significant } \\
\text { delay in the } \\
\text { overall } \\
\text { development }\end{array}$} & \multicolumn{2}{|c|}{$\begin{array}{c}\text { Suggest a } \\
\text { slight delay in } \\
\text { the overall } \\
\text { development }\end{array}$} & \multicolumn{2}{|c|}{$\begin{array}{c}\text { Average } \\
\text { development }\end{array}$} & \multicolumn{2}{|c|}{ Total } & \multirow[t]{2}{*}{ Mean } & \multirow[t]{2}{*}{ Verbal Description } \\
\hline & $\mathbf{F}$ & $\%$ & $\mathbf{F}$ & $\%$ & $\mathbf{F}$ & $\%$ & $\mathbf{F}$ & $\%$ & & \\
\hline First & 12 & 6.35 & 10 & 5.29 & 39 & 20.63 & 61 & 32.28 & 2.44 & $\begin{array}{c}\text { Suggest a slight } \\
\text { delay in the overall } \\
\text { development }\end{array}$ \\
\hline Middle & $\mathrm{O}$ & 0.00 & 1 & 0.53 & 19 & 10.05 & 20 & 10.58 & 2.95 & $\begin{array}{c}\text { Average } \\
\text { development }\end{array}$ \\
\hline Last & 21 & 11.11 & 17 & 8.99 & 36 & 19.05 & 74 & 39.15 & 2.20 & $\begin{array}{c}\text { Suggest a slight } \\
\text { delay in the overall } \\
\text { development }\end{array}$ \\
\hline $\begin{array}{l}\text { Only } \\
\text { child }\end{array}$ & 7 & 3.70 & 6 & 3.17 & 21 & 11.11 & 34 & 17.99 & 2.41 & $\begin{array}{c}\text { Suggest a slight } \\
\text { delay in the overall } \\
\text { development }\end{array}$ \\
\hline Total & 40 & 21.16 & 34 & 17.99 & 115 & 60.85 & 189 & 100 & & \\
\hline
\end{tabular}

Note: Grand Mean: 2.44

Verbal description: Suggest a slight delay in the overall development.

Note: $\mathrm{F}=$ frequency, $\%=$ percentage

It is shown in Table 1 that in terms of their Gross Motor Domain, middle born kindergarten pupils perform better than the pupils with other birth orders since the only middle born pupils have average development during the second assessment of the ECD Checklist.

It can be interpreted that the kindergarten pupils are weak in this developmental domain. During the assessment, only a few among the skills/activities prescribed by the checklist gross motor domain were accomplished. Some of these crafts/activities were: climbing on a chair or other elevated pieces of furniture like a bed without help, walking backward, running without tripping or falling, walking upstairs with other feet without holding the handrail, and moving body part as directed. It is alarming that learners are delayed in this learning domain, considering the study of the National Research Council (2012) which states that sensory and motor developments are critical for everyday and classroom activities that contribute to cognitive development, early learning, and eventually academic achievement. ${ }^{8} \mathrm{With}$ this, it is necessary to strive for the improvement of the kindergarten pupils' gross motor skills through enrichment learning opportunities that can be provided by teachers and can be reinforced by parents/guardians at home.

\subsection{Fine Motor Domain}

A fine motor skill is the ability to control and coordinate hand and finger movements such as copies a simple pattern of different basic shapes and draws a human figure without prompts. Likewise, it is the ability to draw a house without prompts using geometric forms, and coloring with strokes staying within the lines.

Table-2. Achievement of the kindergarten pupils in fine motor domain of early childhood development.

\begin{tabular}{|c|c|c|c|c|c|c|c|c|c|c|}
\hline \multirow{2}{*}{$\begin{array}{l}\text { Birth } \\
\text { Order }\end{array}$} & \multicolumn{2}{|c|}{$\begin{array}{c}\text { Suggest } \\
\text { Significant delay } \\
\text { in the overall } \\
\text { development }\end{array}$} & \multicolumn{2}{|c|}{$\begin{array}{c}\text { Suggest a slight } \\
\text { delay in the } \\
\text { overall } \\
\text { development }\end{array}$} & \multicolumn{2}{|c|}{$\begin{array}{c}\text { Average } \\
\text { development }\end{array}$} & \multicolumn{2}{|c|}{ Total } & \multirow[t]{2}{*}{ Mean } & \multirow[t]{2}{*}{ Verbal Description } \\
\hline & $\mathbf{F}$ & $\%$ & $\mathbf{F}$ & $\%$ & $\mathbf{F}$ & $\%$ & $\mathbf{F}$ & $\%$ & & \\
\hline First & $\bar{O}$ & 0.00 & 5 & 2.65 & 56 & 29.63 & 61 & 32.28 & 2.92 & Average development \\
\hline Middle & $\mathrm{O}$ & 0.00 & $\mathrm{O}$ & 0.00 & 20 & 10.58 & 20 & 10.58 & 3.00 & Average development \\
\hline Last & 3 & 1.59 & 5 & 2.65 & 66 & 34.92 & 74 & 39.15 & 2.85 & Average development \\
\hline Only child & $\mathrm{O}$ & 0.00 & 1 & 0.53 & 33 & 17.46 & 34 & 17.99 & 2.97 & Average development \\
\hline Total & 3 & 1.59 & 11 & 5.82 & 175 & 92.59 & 189 & 100.00 & & \\
\hline
\end{tabular}

Note: Grand mean: 2.91

Verbal Description: Average development

Note: $\mathrm{F}=$ frequency, $\%=$ percentage.

In terms of Fine Motor Skills, most of the pupils attained average development while very few of them have a significant delay in development and slightly delayed.

It can be viewed in Table 2 that the pupils accomplished an average number of skills/activities in the ECD Checklist. Such skills/activities were picking up objects with thumb and index finger, displaying a definite hand preference, putting small objects in/out of containers, holding a crayon with all the fingers of his hand making a fist, scribbling spontaneously and the like. One study found that fine motor skills were strongly linked to later

${ }^{7}$ From Fine motor skills and early comprehension of the world: Two new school readiness indicators. Grissmer et al. (2010). Developmental Psychology

46(5):1008-1017.
${ }^{8}$ From Neurons to Neighborhoods: An Update: Workshop Summary. National Research Council (2012). Washington, DC: The National Academies Press. https://doi.org/10.17226/13119. 
achievement (Grissmer et al., 2010).9 Considering their achievement, kindergarten pupils have standard fine motor skills. Since their performance in this domain was elicited from the 2nd assessment period, teachers have ample time to raise the bar of the pupils' achievement in fine motor skills because this domain has strongly linked to later performance.

\subsection{Self-Help Domain}

Self-help is the ability of kindergarten pupils to become independent in performing tasks such as learning to dress oneself, feed oneself, using the toilet, brushing teeth, bathing, tying shoes, and alike.

\begin{tabular}{|c|c|c|c|c|c|c|c|c|c|c|}
\hline \multirow{2}{*}{$\begin{array}{l}\text { Birth } \\
\text { Order }\end{array}$} & \multicolumn{2}{|c|}{$\begin{array}{c}\text { Suggest } \\
\text { Significant } \\
\text { delay in the } \\
\text { overall } \\
\text { development }\end{array}$} & \multicolumn{2}{|c|}{$\begin{array}{l}\text { Suggest a } \\
\text { slight delay in } \\
\text { the overall } \\
\text { development }\end{array}$} & \multicolumn{2}{|c|}{$\begin{array}{c}\text { Average } \\
\text { development }\end{array}$} & \multicolumn{2}{|c|}{ Total } & \multirow[t]{2}{*}{ Mean } & \multirow[t]{2}{*}{ Verbal Description } \\
\hline & $\mathbf{F}$ & $\%$ & $\mathbf{F}$ & $\%$ & $\mathbf{F}$ & $\%$ & $\mathbf{F}$ & $\%$ & & \\
\hline First & 31 & 16.40 & 14 & 7.41 & 16 & 8.47 & 61 & 32.28 & 1.75 & $\begin{array}{c}\text { Suggest Significant } \\
\text { delay in the overall } \\
\text { development }\end{array}$ \\
\hline Middle & 13 & 6.88 & 5 & 2.65 & 2 & 1.06 & 20 & 10.58 & 1.45 & $\begin{array}{c}\text { Suggest } \\
\text { Significant delay in the } \\
\text { overall development }\end{array}$ \\
\hline Last & 32 & 16.93 & 23 & 12.17 & 19 & 10.05 & 74 & 39.15 & 1.82 & $\begin{array}{c}\text { Suggest a slight delay } \\
\text { in the overall } \\
\text { development }\end{array}$ \\
\hline $\begin{array}{l}\text { Only } \\
\text { child }\end{array}$ & 16 & 8.47 & 8 & 4.23 & 10 & 5.29 & 34 & 17.99 & 1.82 & $\begin{array}{c}\text { Suggest a slight delay } \\
\text { in the overall } \\
\text { development }\end{array}$ \\
\hline Total & 92 & 48.68 & 50 & 26.46 & 47 & 24.87 & 189 & 100.00 & & \\
\hline
\end{tabular}

Note: Grand mean: 1.76
Verbal Description: Suggest Significant delay in the overall development

Note: $\mathrm{F}=$ frequency, $\%=$ percentage.

In the Self-help domain, as presented in Table 3, almost half of the pupils have significantly delayed development while few of them were slightly delayed and averagely developed. In terms of the class performance, the kindergarten pupils are delayed considerably in overall self-help development since the computed grand mean is 1.76. Results revealed that this is the weakest domain of the pupils. These results can be interpreted that during the assessment period, many indicators such as feeding self with finger food using fingers, eating without a need for spoon-feeding during any meal and bathing were not accomplished. Same with drinking from a cup without spillage, dressing without assistance except for buttons and tying, going to the designated place to urinate (pee) or move bowels (pooh), and never does this is his underpants anymore and the like.

The result of the present study is very alarming because this domain prepares children to become independent in later years as well as self-assurance, accountability, and responsibility. Hence, home and school can offer learning opportunities for learners to develop self-help skills and give them ample time to work on these essential tasks. Adults shall play an indispensable role as models; children learn a great deal from watching people around them, especially their parents/ guardians and teachers.

\subsection{Receptive Language Domain}

Receptive language domain refers to the understanding of language "input." It includes the knowledge of words and gestures. It goes beyond just vocabulary skills, but also the knowledge of concepts like "on" and the ability to understand a question as a question.

Table-4. Achievement of the kindergarten pupils in receptive language domain of early childhood development.

\begin{tabular}{|c|c|c|c|c|c|c|c|c|c|c|}
\hline \multirow{2}{*}{$\begin{array}{l}\text { Birth } \\
\text { Order }\end{array}$} & \multicolumn{2}{|c|}{$\begin{array}{c}\text { Suggest } \\
\text { Significant delay } \\
\text { in the overall } \\
\text { development }\end{array}$} & \multicolumn{2}{|c|}{$\begin{array}{l}\text { Suggest a } \\
\text { slight delay in } \\
\text { the overall } \\
\text { development }\end{array}$} & \multicolumn{2}{|c|}{$\begin{array}{c}\text { Average } \\
\text { development }\end{array}$} & \multicolumn{2}{|c|}{ Total } & \multirow{2}{*}{ Mean } & \multirow{2}{*}{ Verbal Description } \\
\hline & $\mathbf{F}$ & $\%$ & $\mathbf{F}$ & $\%$ & $\mathbf{F}$ & $\%$ & $\mathbf{F}$ & $\%$ & & \\
\hline First & 2 & 1.06 & 12 & 6.35 & 47 & 24.87 & 61 & 32.28 & 2.74 & Average development \\
\hline Middle & 3 & 1.59 & 5 & 2.65 & 12 & 6.35 & 20 & 10.58 & 2.45 & $\begin{array}{l}\text { Suggest a slight delay in the } \\
\text { overall development }\end{array}$ \\
\hline Last & 8 & 4.23 & 16 & 8.47 & 50 & 26.46 & 74 & 39.15 & 2.57 & $\begin{array}{l}\text { Suggest a slight delay in the } \\
\text { overall development }\end{array}$ \\
\hline $\begin{array}{l}\text { Only } \\
\text { child }\end{array}$ & 4 & 2.12 & 8 & 4.23 & 22 & 11.64 & 34 & 17.99 & 2.53 & $\begin{array}{l}\text { Suggest a slight delay in the } \\
\text { overall development }\end{array}$ \\
\hline Total & 17 & 8.99 & 41 & 21.69 & 131 & 69.31 & 189 & 100 & & \\
\hline
\end{tabular}

Verbal Description: Average development.

Note: $\mathrm{F}=$ frequency, $\%$ = percentage.

${ }^{9}$ From Fine motor skills and early comprehension of the world: Two new school readiness indicators. Grissmer et al. (2010). Developmental Psychology $46(5): 1008-1017$ 
Table 4 shows that the achievement of first-born kindergarten pupils is higher than the other birth orders. The majority of the pupils were averagely developed; and, few of them were slightly delayed and significantly delayed in development. It means that few of the pupils are very weak in their ability to understand both verbal and nonverbal communication.

This result further revealed that with the grand mean of 2.60, kindergarten pupils' achievement in the receptive language domain is average. It can be viewed that the kindergarten pupils performed some of the skills successfully. These were pointing to a family member, leading to 5 body parts on himself, pointing to 5 named pictured objects, following one-step instructions that include simple prepositions (e.g., in, on, under, etc.), and following 2 -step instructions that include simple prepositions.

The interrelatedness of the domains is evident in the study conducted by the National Research Council (2015). ${ }^{10}$ It states that awareness of the benefits and pitfalls of the language used by adults is essential for interaction with learners. The language used by adults affects the learning and cognitive growth of learners in many subtle ways. Labeling is a powerful way to foster conceptual development. Simple labels can help children unify diverse things into coherent categories, but can also have the unintended consequence of reinforcing concepts that are not desirable.

\subsection{Expressive Language Domain}

Expressive Language skill is their ability of kindergarten pupils to use words and gestures to express his thoughts and feelings, e.g., draw and tell a story about his drawing.

Table-5. Achievement of the kindergarten pupils in expressive language domain of early childhood development.

\begin{tabular}{|c|c|c|c|c|c|c|c|c|c|c|}
\hline \multirow{2}{*}{$\begin{array}{l}\text { Birth } \\
\text { Order }\end{array}$} & \multicolumn{2}{|c|}{$\begin{array}{c}\text { Suggest } \\
\text { Significant } \\
\text { delay in the } \\
\text { overall } \\
\text { development }\end{array}$} & \multicolumn{2}{|c|}{$\begin{array}{c}\text { Suggest a } \\
\text { slight delay in } \\
\text { the overall } \\
\text { development }\end{array}$} & \multicolumn{2}{|c|}{$\begin{array}{c}\text { Average } \\
\text { development }\end{array}$} & \multicolumn{2}{|c|}{ Total } & \multirow{2}{*}{ Mean } & \multirow{2}{*}{ Verbal Description } \\
\hline & $\mathbf{F}$ & $\%$ & $\mathbf{F}$ & $\%$ & $\mathbf{F}$ & $\%$ & $\mathbf{F}$ & $\%$ & & \\
\hline First & 6 & 3.17 & 50 & 26.46 & 5 & 2.65 & 61 & 32.28 & 1.98 & $\begin{array}{l}\text { Suggest a slight delay in the } \\
\text { overall development }\end{array}$ \\
\hline Middle & 5 & 2.65 & 13 & 6.88 & 2 & 1.06 & 20 & 10.58 & 1.85 & $\begin{array}{l}\text { Suggest a slight delay in the } \\
\text { overall development }\end{array}$ \\
\hline Last & 11 & 5.82 & 58 & 30.69 & 5 & 2.65 & 74 & 39.15 & 1.92 & $\begin{array}{l}\text { Suggest a slight delay in the } \\
\text { overall development }\end{array}$ \\
\hline $\begin{array}{l}\text { Only } \\
\text { child }\end{array}$ & 0 & 0.00 & 26 & 13.76 & 8 & 4.23 & 34 & 17.99 & 2.24 & $\begin{array}{l}\text { Suggest a slight delay in the } \\
\text { overall development }\end{array}$ \\
\hline Total & 22 & 11.64 & 147 & 77.78 & 20 & 10.58 & 189 & 100.00 & & \\
\hline
\end{tabular}

Note: Grand Mean: 1.99

Verbal Description: Suggest a slight delay in the overall development.

Note: $\mathrm{F}=$ frequency, $\%=$ percentage.

In terms of expressive language, the majority of the pupils have a slight delay in development, while few have a significant delay in growth and healthy development.

Table 5 revealed that the pupils' overall development in expressive language is slightly delayed. The results can be interpreted that during the second assessment of the checklist, very few among the activities were performed correctly by the pupils. Some of these tasks of the pupils were using 5-20 recognizable words, using pronouns (e.g., I, me, mine), naming objects in pictures, asking "who" and "why" questions, giving an account of recent experiences (with prompting) in order of occurrence using past tense and the like.

\subsection{Cognitive Domain}

The cognitive domain refers to the ability of kindergarten pupils to understand concepts, their logical relations, and consequently manipulate them to arrive at new knowledge, ideas, or conclusions.

Teachers and parents in this regard should be cautious about underestimating children's cognitive abilities. National Research Council (2015) posits that the potential to underestimate young learners' cognitive abilities continues in the preschool and kindergarten years. In one study, for example, learner's actual performance was six to eight times what was estimated by their preschool teachers and other experts. ${ }^{11}$ This underestimation draws a lost opportunity that can hinder learner's progress. It was revealed in a study in Kindergarten that learners benefited more from advanced reading and mathematics content. Unfortunately, teachers spent most of the academic time primary contents which learners already knew (Claessens, Engel, \& Curran, 2014).12 Moreover, when education professionals and practitioners underestimate learner's abilities to understand and learn subjectmatter content, those with less prior learning experiences were negatively affected (Clements \& Sarama, 2014).13

Table 6 shows that the only middle-born kindergarten pupils are slightly delayed in their overall cognitive development; the other birth orders are average in their development. On the other hand, only two kindergarten pupils, first- and last-born was slightly advanced. With the grand mean of 2.64, kindergarten pupils' overall development in the cognitive domain is average. Results further revealed that kindergarten pupils' ability to look at the direction of the fallen object, match objects, sort based on shapes, arrange objects according to size from smallest to biggest, name three animals or vegetables, assemble simple puzzles and the like is average.

\footnotetext{
${ }^{10}$ From National Research Council (2015).

${ }^{11}$ From National Research Council (2015).

${ }^{12}$ From Claessens et al. (2014).
${ }^{13}$ From Clements and Sarama (2014).

${ }^{14}$ From National Research Council (2012).
} 
Table-6. Achievement of the kindergarten pupils in cognitive domain of early childhood development.

\begin{tabular}{|c|c|c|c|c|c|c|c|c|c|c|c|c|}
\hline \multirow{2}{*}{$\begin{array}{l}\text { Birth } \\
\text { Order }\end{array}$} & \multicolumn{2}{|c|}{$\begin{array}{c}\text { Suggest } \\
\text { Significant } \\
\text { delay in the } \\
\text { overall } \\
\text { development }\end{array}$} & \multicolumn{2}{|c|}{$\begin{array}{c}\text { Suggest a } \\
\text { slight delay } \\
\text { in the } \\
\text { overall } \\
\text { development }\end{array}$} & \multicolumn{2}{|c|}{$\begin{array}{c}\text { Average } \\
\text { development }\end{array}$} & \multicolumn{2}{|c|}{$\begin{array}{c}\text { Suggest } \\
\text { slightly } \\
\text { advanced } \\
\text { development }\end{array}$} & \multicolumn{2}{|c|}{ Total } & \multirow[t]{2}{*}{ Mean } & \multirow[t]{2}{*}{$\begin{array}{c}\text { Verbal } \\
\text { Description }\end{array}$} \\
\hline & $\mathbf{F}$ & $\%$ & $\mathbf{F}$ & $\%$ & $\mathbf{F}$ & $\%$ & $\mathbf{F}$ & $\%$ & $\mathbf{F}$ & $\%$ & & \\
\hline First & 4 & 2.12 & 12 & 6.35 & 44 & 23.28 & 1 & 0.53 & 61 & 32.28 & 2.69 & $\begin{array}{c}\text { Average } \\
\text { development }\end{array}$ \\
\hline Middle & 5 & 2.65 & 2 & 1.06 & 13 & 6.88 & $\mathrm{O}$ & 0.00 & 20 & 10.58 & 2.40 & $\begin{array}{c}\text { Suggest a slight } \\
\text { delay in the } \\
\text { overall } \\
\text { development }\end{array}$ \\
\hline Last & 8 & 4.23 & 10 & 5.29 & 55 & 29.10 & 1 & 0.53 & 74 & 39.15 & 2.66 & $\begin{array}{c}\text { Average } \\
\text { development }\end{array}$ \\
\hline $\begin{array}{l}\text { Only } \\
\text { child }\end{array}$ & 3 & 1.59 & 6 & 3.17 & 25 & 13.23 & $\mathrm{O}$ & 0.00 & 34 & 17.99 & 2.65 & $\begin{array}{c}\text { Average } \\
\text { development }\end{array}$ \\
\hline Total & 20 & 10.58 & 30 & 15.87 & 137 & 72.49 & 2 & 1.06 & 189 & 100 & & \\
\hline
\end{tabular}

Note: Grand Mean: 2.64

Verbal Description: Average development

Note: $\mathrm{F}=$ frequency, $\%=$ percentage.

In this regard, teachers and parents should provide learning opportunities that are developmentally appropriate for children's abilities and readiness. National Research Council (2012) emphasized that learning begins prenatally; children are not only "ready to learn" but already actively learning, which started when they are born. ${ }^{14}$ From birth, children's minds are curious and active, and early thinking is insightful and obscure. Many of the foundations of complex forms of learning are established in the earliest stages of life. Development and early education can be supported continuously as a child develops, and new knowledge and skills inform and influence future learning. When adults understand how the mind grows, how active inquiry and learning are children's natural inclination, and what progress learners make in their cognitive abilities, they can nurture cognitive growth. Adults can support learner's active engagement with new learning experiences. They can provide developmentally appropriate opportunities for further learning.

\subsection{Socio-Emotional Domain}

Through structured and unstructured, games, activities, play, and interaction with other people, young learners process information about their world. From these experiences, they develop their understanding and abilities in Math, Science, and Language. The mind of a young child is like a sponge that absorbs information. On the other hand, learners who are unable to self-regulate have emotional difficulties that may hinder learning. As with younger learners, significant adults in a child's life can help the child learn to self-regulate (Tomlinson, 2014). ${ }^{15}$ If this is so, it is necessary to analyze the socio-emotional domain of children.

Table-7. Achievement of the kindergarten pupils in socio-emotional domain of early childhood development.

\begin{tabular}{|c|c|c|c|c|c|c|c|c|c|c|}
\hline \multirow[b]{2}{*}{$\begin{array}{l}\text { Birth } \\
\text { Order }\end{array}$} & \multicolumn{2}{|c|}{$\begin{array}{c}\text { Suggest } \\
\text { Significant } \\
\text { delay in the } \\
\text { overall } \\
\text { development }\end{array}$} & \multicolumn{2}{|c|}{$\begin{array}{c}\text { Suggest a } \\
\text { slight delay } \\
\text { in the } \\
\text { overall } \\
\text { development }\end{array}$} & \multicolumn{2}{|c|}{$\begin{array}{c}\text { Average } \\
\text { development }\end{array}$} & \multicolumn{2}{|c|}{ Total } & \multirow[t]{2}{*}{ Mean } & \multirow[t]{2}{*}{ Verbal Description } \\
\hline & $\mathbf{F}$ & $\%$ & $\mathbf{F}$ & $\%$ & $\mathbf{F}$ & $\%$ & $\mathbf{F}$ & $\%$ & & \\
\hline First & 13 & 6.88 & 25 & 13.23 & 23 & 12.17 & 61 & 32.28 & 2.16 & $\begin{array}{c}\text { Suggest a slight delay in the overall } \\
\text { development }\end{array}$ \\
\hline Middle & 8 & 4.23 & 7 & 3.70 & 5 & 2.65 & 20 & 10.58 & 1.85 & $\begin{array}{l}\text { Suggest a slight delay in the overall } \\
\text { development }\end{array}$ \\
\hline Last & 19 & 10.05 & 28 & 14.81 & 27 & 14.29 & 74 & 39.15 & 2.11 & $\begin{array}{l}\text { Suggest a slight delay in the overall } \\
\text { development }\end{array}$ \\
\hline $\begin{array}{l}\text { Only } \\
\text { child }\end{array}$ & 9 & 4.76 & 12 & 6.35 & 13 & 6.88 & 34 & 17.99 & 2.12 & $\begin{array}{l}\text { Suggest a slight delay in the overall } \\
\text { development }\end{array}$ \\
\hline Total & 49 & 25.93 & 72 & 38.10 & 68 & 35.98 & 189 & 100 & & \\
\hline
\end{tabular}

Note: Grand Mean: 2.10

Verbal Description: Suggest a slight delay in the overall development.

Note: $\mathrm{F}=$ frequency, $\%=$ percentage.

As shown in Table 7, kindergarten pupils' achievement in the socio-emotional domain is slightly delayed in any birth order. It means that the majority of pupils are weak in their ability to know themselves, express and understand feelings, and relate to others.

The results further revealed that the kindergarten pupils completed only a few among the skills during the assessment. Some of these skills/activities were playing alone but liked to be near familiar adults or brothers and sisters, demonstrating respect for elders, sharing toys with others, identifying feelings in others, helping with family chores (e.g., wiping tables, watering plants, etc.) and other activities prescribed by the checklist.

Socio-emotional development contributes to the growth of emotional security that enables young children to fully invest in new learning and to the growth of cognitive skills and competencies that are important for 
education. These capacities are essential because knowledge is inherently a social process. Young learner's relationships — with parents, teachers, and peers as well as the members of the community - thus are fundamental to the learning experiences that contribute to their later success (National Research Council, 2012). ${ }^{16}$ It is alarming that pupils are slightly delayed in this domain. In this regard, teachers, parents, and other stakeholders must work hand and hand for its improvement. Parents have a significant function in the development of character and values of children; this starts at home. Building good character and values which are intertwined in socio-emotional skills are best learned through role modeling. Teachers, on the other hand, have a role in reinforcing taught values and socio-emotional skills at home. Anyone who has direct contact with each child can affect his/her socio-emotional development - how they were treated, valued, and cared.

\subsection{Relationship of Kindergarten Pupils' Birth Order to their Achievement in Domains of Early Childhood Development}

Birth order refers to the chronological order of sibling births in a family (first-born, last-born, middle-born, only-child). On the other hand, gross motor, fine motor, self-help, receptive language, expressive language, cognitive, and socio-emotional composes the domains early childhood development.

Table-8. Relationship of kindergarten pupils' birth order and achievement in domains of early childhood development.

\begin{tabular}{c|c|c|c}
\hline The domain of Early Childhood Development & p-value & Level of Significance & Interpretation \\
\hline Gross Motor & 0.02 & 0.05 & Significant \\
\hline Fine Motor & 0.29 & 0.05 & Not Significant \\
\hline Self-help & 0.58 & 0.05 & Not Significant \\
\hline Receptive & 0.57 & 0.05 & Not Significant \\
\hline Expressive & 0.02 & 0.05 & Significant \\
\hline Cognitive & 0.37 & 0.05 & Not Significant \\
\hline Socio-emotional & 0.08 & 0.05 & Not Significant \\
\hline Note: $\mathrm{F}=$ frequency, $\%=$ percentage.
\end{tabular}

It made use of the chi-square test to examine the relationship between kindergarten pupils' birth order and their achievement in domains of early childhood development. Only the relation of birth order to expressive language and gross motor domains of kindergarten pupils was significant since the computed p-value is less than the 0.05 level of significance.

It can be interpreted in Table 8 that their gross motor performance, such as climbing on a chair or other elevated piece of furniture without help, walking backward, and running without tripping or falling, has a significant relationship to birth order. Further, walking upstairs with other feet without holding the handrail and moving body part as directed has a substantial connection to the sibling arrangement. Meanwhile, in terms of the performance of the kindergarten pupils concerning their birth order, the only middle born children are average achievers while other birth orders are slightly delayed.

On the other hand, expressive language is most merely the "output" of writing, how children express their wants and needs. This domain includes not only words but also grammar rules that dictate how these words are combined into clauses, phrases, sentences, and paragraphs and the use of gestures and facial expressions. Credit must also be given to the gestural cues and facial expressions that pupils use and react to as it is an earlydeveloping and valuable skill.

Statistically, this domain has a significant relationship with birth order. In terms of the achievement of the kindergarten pupils in their expressive language concerning their sibling arrangement, pupils who are only child perform better than the pupils with other birth order. With this, it can be inferred that since only child pupil has his/her attention at home, he/she is more exposed to conversations and another form of communication, which enhances his/her expressive language skills.

\section{Conclusions}

This study primarily aimed to determine the relationship of kindergarten pupils' birth order, and achievement in domains of early childhood development at Santa Ignacia North District, Tarlac, Philippines enrolled during the school year 2015-2016. The present study is unique and will fill the gap in birth order and academic achievement studies since all of the respondents on all conducted studies analyzing the effects of birth order on the academic achievements of students: elementary, high school, and college students. Hence, the findings of the present study are significant and essential as additional empirical results of those researches conducted to look at the relationship of birth order to pupils' academic achievement, highlighting early childhood education, particularly kindergarten education.

The findings of the present study revealed that most of the kindergarten pupils are last-born and firstborn children. And few are middle-born and only-child pupils. On the other hand, the overall achievement of the kindergarten pupils in fine motor, receptive language, and cognitive domains is average. Simultaneously, they are slightly delayed in gross motor, self-help, expressive language, and socio-emotional domains. These domains of learning are interrelated to each other; these have equal importance and significance to the attainment of holistic development. Thus, it is necessary to improve fields, especially delayed ones.

On the one hand, gross motor and expressive language are the domains of early childhood development that have a significant relationship with kindergarten pupils' birth order. Only middle-born children have average growth in the gross motor; the other birth orders are slightly delayed. Meanwhile, pupils who are only child perform better in expressive language domain than the pupils with different birth order- firstborn, middle born and last born. In this light, we can infer that, since the only child pupil has the individual attention at home, he/she is the sole recipient of any form of communication, both verbal and non-verbal, which can contribute to the development of expressive language.

${ }^{16}$ From National Research Council (2012). 
Hence, the present study concludes that birth order has something to do with pupils' academic achievement not only to elementary, high school and college students but also as young as a kindergarten pupil, especially in gross motor and expressive domains of early childhood development.

\section{Recommendations}

It is the shortcoming of the present study to look for the possible reasons or causes why respondents' achievement in some domains of early childhood development is delayed; gaps in years between birth orders were not also considered. With this, it is recommended to consider these variables for future research direction. Also, further research has to be conducted considering other localities and broader scope for more conclusive findings. On the other hand, based on the results and conclusions, it is recommended that kindergarten teachers may consider the significant relationship of birth order and gross motor and expressive language domains in providing learning opportunities to kindergarten pupils. Birth order may be used as a grouping strategy to enhance a specific field of learning. Meanwhile, school administrators should provide kindergarten teachers with continual exposure and training to deal with the improvement of kindergarten pupils' achievement in the realms of early childhood development.

\section{References}

Claessens, A., Engel, M., \& Curran, F. C. (2014). Academic content, student learning, and the persistence of preschool effects. American Educational Research Journal, 51(2), 403-434.Available at: https://doi.org/10.3102/0002831213513634.

Clements, D. H., \& Sarama, J. (2014). Learning and teaching early math: The learning trajectories approach (2nd ed.). New York: Routledge.

Copple. (2009). Developmentally appropriate practices in early childhood program: Serving children from birth through age Eight. USA: National Association for the Education of Young Children (NAEYC).

Dailey, K. M. (2012). Birth order and its effect on motivation and academic achievement. Journal of Personality and Individual Differences, $40(5), 953-959$

Grissmer, D., Grimm, K. J., Aiyer, S. M., Murrah, W. M., \& Steele, J. S. (2010). Fine motor skills and early comprehension of the world: Two new school readiness indicators. Developmental Psychology, 46(5), 1008-1017.Available at: https://doi.org/10.1037/a0020104.

Ha, T. S., \& Tam, C. L. (2011). A study of birth order, academic performance, and personality. Singapore: IACSIT Press.

Hotz, V. J., \& Pantano, J. (2015). Strategic parenting, birth order, and school performance. Journal of Population Economics, 28(4), $911-$ 936.Available at: https://doi.org/10.1007/s00148-015-0542-3.

National Research Council. (2012). From neurons to neighborhoods: An update: Workshop summary. Washington, DC: The National Academies Press.

National Research Council. (2015). Transforming the workforce for children birth through age 8: A unifying foundation. Washington, DC: The National Academies Press.

Philippines, R. O. (2012). Republic act No. 10157. Manila, NCR.Republic Act. Retrieved from: https:// www.officialgazette.gov.ph/.

Sicat, L. V. (2009). Work text in research writing (pp. 30-31). Tarlac: Tarlac State University.

Tomlinson, H. B. (2014). An overview of development in the primary grades. In Developmentally appropriate practice (pp. 9-38). Washington, DC: National Association for the Education of Young Children. 